Pesq. Vet. Bras. 28(1):43-50, janeiro 2008

\title{
Experimental poisoning by Senecio brasiliensis in calves: quantitative and semi-quantitative study on changes in the hepatic extracellular matrix and sinusoidal cells ${ }^{1}$
}

\author{
Márcia Bersane A.M. Torres ${ }^{2}$ and Kunie I.R. Coelho ${ }^{3}$
}

\begin{abstract}
Torres M.B.A.M. \& Coelho K.I.R. 2008. Experimental poisoning by Senecio brasiliensis in calves: quantitative and semi-quantitative study on changes in the hepatic extracellular matrix and sinusoidal cells. Pesquisa Veterinária Brasileira 28(1):43-50. Laboratório de Patologia Veterinária, Universidade Federal do Paraná, Campus Palotina, Rua Pioneiro 2153, Jardim Dallas, Palotina, PR 85950-000, Brazil. E-mail: torres@ ufpr.br

Extracellular matrix plays an important role in chronic hepatic lesions and has been studied in experimental intoxication models. However in cattle, studies on chronic disease have focused on the hepatocellular damage and extracellular matrix (ECM) changes are usually overlooked. There are no specific studies on the hepatic ECM in either normal or chronically damaged bovine liver. Thus an experimental model of hepatic toxicity model using Senecio brasiliensis poisoned calves was designed. Senecio brasiliensis contains pyrrolizidine alkaloids which cause either acute or chronic progressive dose dependent liver damage. Five calves were orally fed with $0.38 \mathrm{~g}$ of dry leaves of $S$. brasiliensis $/ \mathrm{kg} /$ day for 24 days. Liver needle biopsy specimens were obtained every 15 days for 60 days. Clinical signs of digestive complications appeared at $3^{\text {rd }}$ week. One calf died on $45^{\text {th }}$ day and four were evaluated up to $60^{\text {th }}$ day. Biopsy samples were processed for routine light microscopy, immuno-histochemistry and transmission electron microscopy. From $30^{\text {th }}$ day on progressive liver damage characterized by hepatocellular ballooning, necrosis, apoptosis and megalocytosis, centrilobular, pericellular and portal fibrosis were seen by light microscopy. Quantitative and semi-quantitative measurements of hepatic ECM components were performed before and after the onset of lesions. Morphometric analysis of total collagen and elastic fiber system was conducted. Total collagen and I and III collagen types progressively increased in throughout the liver of affected calves. Changes in location, amount and disposition of the elastic fiber system were also observed. Then numbers of Kupffer cells were significantly increased at $30^{\text {th }}$ day and total numbers of sinusoidal cells were significantly increased at $45^{\text {th }}$ and $60^{\text {th }}$ days. Liver damage was progressive and irreversible even after the exposure to the plant was discontinued. Severe fibrotic lesions occurred mainly in portal tracts, followed by veno-occlusive and pericellular fibrosis. Collagen types I and III s were present in every normal and damaged liver, with predominance of type I. In affected calves the increase of total collagen and elastic fibers system paralleled the number of total sinusoidal cells.
\end{abstract}

INDEX TERMS: Hepatic extracellular matrix, sinusoidal cells, hepatic fibrosis, pyrrolizidine alkaloids.

${ }^{1}$ Received on June 26, 2007.

Accepted for publication on October 23, 2007.

Parte da Tese de Doutorado da primeira autora, Programa de PósGraduação em Patologia, Faculdade de Medicina, Universidade Estadual Paulista (Unesp), Campus de Botucatu.

${ }^{2}$ Laboratório de Patologia Veterinária, Universidade Federal do Paraná, Campus Palotina, Rua Pioneiro 2153, Jardim Dallas, Palotina, PR 85950-000, Brazil. *Corresponding author: torres@ ufpr.br

${ }^{3}$ Departamento de Patologia, Faculdade de Medicina, Unesp-Botucatu, Distrito de Rubião Junior, Botucatu, SP 18618-000 Brazil.
RESUMO.- [Intoxicação experimental por Senecio brasiliensis em bovinos: estudo quantitativo e semi-quantitativo da matrix extracelular e de células sinusoidais do fígado.] A matriz extracelular (MEC) desempenha um papel importante em lesões hepáticas crônicas e tem sido estudada em modelos de intoxicação experimental. Em bovinos, no entanto, não há estudos específicos sobre a MEC hepática normal ou com lesões crônicas. Por isso, foi desenvolvido um modelo de intoxicação experimental he- 
pático usando Senecio brasilliensis, uma planta que contém alcalóides pirrolizidínicos e causa lesão hepática dependente da dose. Cinco bezerros receberam por via oral, $0.38 \mathrm{~g} / \mathrm{kg}$ de folhas secas por 24 dias. Biópsias hepáticas foram obtidas a cada 15 dias durante 60 dias. Sinais clínicos de complicações digestivas surgiram da terceira semana do experimento. Um bezerro morreu aos 45 dias e os outros quatro foram avaliados até os 60 dias. As biópsias hepáticas foram processadas para microscopia óptica, imuno-histoquímica e microscopia eletrônica de transmissão. No trigésimo dia, as lesões hepáticas eram progessivas caracterizadas por vacuolização hepatocelular, necrose, apoptose, megalocitose, e fibrose centrolobular, pericelular e portal. Foram realizadas avaliações quantitativas e semiquantitativas de componentes da MEC hepática antes e após o aparecimento das lesões. Foi realizada morfometria do colágeno total e do sistema de fibras elásticas. Colágeno total e colágenos tipos I e III aumentaram progressivamente em todos os locais do fígado. Mudanças na localização, quantidade e disposição do sistema de fibras elásticas foram também observadas. Houve um aumento significativo de células de Kupffer aos 30 dias e de células sinusoidais totais aos 45 e 60 dias. As lesões hepáticas neste experimento foram progressivas mesmo após a remoção da planta. Lesões de fibrose severa foram localizadas principalmente nos espaços porta, seguido por fibrose veno-oclusiva e pericelular. Os colágenos tipo I e tipo III foram observados no fígado normal e no fígado dos bezerros afetados, com predomínio do tipo I. Nos bezerros afetados o aumento do colágeno total e do sistema de fibras elásticas foi paralelo ao aumento no número das células sinusoidais.

TERMOS DE INDEXAÇÃO: Matriz extracelular hepatica, células sinusoidais, fibrose hepática, alcalóides pirrolizidínicos.

\section{INTRODUCTION}

Pyrrolizidine alkaloids are poisonous substances present in many plants, particularly in those of the genus Senecio. $S$. brasiliensis is one of more toxic species of the genus Senecio (Tokarnia \& Döbereiner 1984). The main lesions observed in cows caused by ingestion of these alkaloids are liver fibrosis and liver failure; however the lungs and kidneys may be also damaged (Tokarnia \& Döbereiner 1984, Hill et al. 1997, Torres et al. 1997).

Microscopically the liver shows portal tract fibroplasia, bile duct hyperplasia and hepatocellular megalocytosis (Méndez et al. 1987, Barros et al. 1992). In humans, partial or total centrilobular venous occlusion by fibrotic tissue resulting in veno-occlusive disease, is described (Ridker et al. 1985, Odriozola et al. 1994, Prakash et al. 1999).

The primary function of extracellular matrix $(E C M)$ is to provide a physical scaffold for hepatocytes. However, it also plays a role as modulator of biologic processes including cell attachment, migration, differentiation, repair and development (Martinez-Hernandez 1984, Schuppan et al. 2001). The main classes of ECM components are polysaccharide chains referred to as glycosaminoglycans, which are generally associated with proteins such as proteoglycans, fibrous structural proteins such as collagen, elastin and adhesive fibrous proteins such as fibronectin and laminin (Albert et al. 1994). The various collagen types in the liver are produced mainly by sinusoidal cells and hepatocytes and are the main components studied in either normal, with fibrosis or cirrhotic liver (Martinez-Hernandez 1984, Geerts 2001).

Sinusoidal cells are consistis of four types of nonparenchymal cells: Kupffer cells, hepatic stellate cells (Ito cells), endothelial cells and pit cells (limphocytes associated to liver) (Shiratori et al. 1993). Endothelial sinusoidal cells and of the portal tracts and hepatic stellate cells, are capable of producing and secret the components of the hepatic ECM (Geerts 2001). Within the liver, the components of the hepatic scar are similar regardless the type of initial injury, whether viral, toxic, immune or metabolic (Olaso \& Friedman, 1998).

As the liver becomes fibrotic, significant qualitative changes of the extracellular matrix (ECM) occur predominantly in the periportal and perisinusoidal space, while the total content of collagens and noncollagenous components increases up to tenfold (Schuppan et al. 2001). ECM components of normal and chronically damaged liver by different etiologies have been studied due to their relevant role in pathologic processes.

Extracellular matrix plays an important role in chronic hepatic lesions and has been studied in experimental intoxication models. However there are no specific studies on the hepatic ECM in either normal or chronically damaged bovine liver. This study was designed to follow sequential hepatocellular damage and ECM changes in cattle poisoned by $S$. brasiliensis.

\section{MATERIALS AND METHODS}

Calves. Five crossbred, 8-month-old calves weighing approximately $140 \mathrm{~kg}$ each were used. Calves were considered healthy based on clinical history, physical examination, hematologic data, histology of the liver observed on percutaneous needle biopsy and serum aminotransferase levels prior to the experimental trial. All five calves were similarly fed with a standard grass diet and water ad libitum.

Plant. Dry Senecio brasiliensis leaves were orally administered in daily doses of $0.38 \mathrm{~g}$ per $\mathrm{kg}$ of body weight for 24 days. Dose and period of plant administration were based on a previous pilot trial experiment. Samples of $S$. brasiliensis used in this trial were identified by a Toxicology Center in Universidade Federal do Rio Grande do Sul, Porto Alegre, Brazil, to ensure toxin source.

Experiment. All procedures were conducted at Faculdade de Medicina Veterinária, Universidade Estadual Paulista at Botucatu, Brazil. All calves were daily submitted to clinical examination. Each calf was submitted to five percutaneous needle liver biopsies taken befre the trial and at 15-day intervals for 60 days after that $\left(T_{1}=\right.$ pre-trial biopsy; $T_{2}=15^{\text {th }} ; T_{3}=30^{\text {th }}$; $\mathrm{T}_{4}=45^{\text {th }}$, and $\mathrm{T}_{5}=60^{\text {th }}$ ). Biopsies were performed under local anesthesia with a $0.3 \mathrm{~cm} \times 11.0 \mathrm{~cm}$ needle especially made for this purpose (Medeiros et al. 2002). Liver samples measuring $2.5 \mathrm{~cm}$ to $3.5 \mathrm{~cm}$ in length and $0.3 \mathrm{~cm}$ in width were obtained and cut in three pieces for routine light microscopy, immunohistochemistry and transmission electron microscopy. 
Light microscopy. Every first piece cut from each liver biopsy was fixed in $10 \%$ formaldehyde, embedded in paraffin and 4ìm thick sections were stained by the hematoxylin-eosin, Masson's trichrome, Jones's silver, Picrossirius Red and Weigert resorcin-fuchsin techniques. Semi-quantitative study was performed, grading the lesions from 0 to $4(0=$ absent; $1=$ minimal; $2=$ mild; $3=$ moderate; $4=$ severe) based on the pilot experiment. Quantitative evaluation of elastic fibers and total collagen were also performed. Measurements were performed using a semi-automated Videoplan image analyzing device ${ }^{4}$. Elastic fiber density was measured by counting ten fields on liver sections stained by the Weigert Resorcin-Fuchsin method (Montes 1992). Total collagen was evaluated by counting twenty fields of $109,495 \mathrm{~mm}^{2}$ each on liver sections stained by Picrossirius Red technique (James et al. 1990). The sum of areas was calculated and final results were expressed in $\mathrm{mm}^{2}$.

Transmission electron microscopy. Part of the hepatic biopsy was fixed in $2.5 \%$ glutaraldehyde in $0.1 \mathrm{M}$ phosphate buffer, post fixed in 1\% osmiun tetroxide in the same buffer. Ultrathin sections were obtained using Ultramicrotome Reichert-Jung/Supernova and stained with uranyl acetate and lead citrate. Photomicrographs were made from sections of two tissue blocks using an electron microscope LEO900, Carl Zeiss. Quantification of sinusoidal cells was obtained using appropriate software (KS100, Carl Zeiss) from a computer connected to a camera (model XC-77, Sony, Tokyo, Japan). Two ultrathin sections at $1,100 x$ magnification were used for sinusoidal cells and hepatocyte counting in twenty fields from the midzonal area.

Immunohistochemistry. Part of each liver sample was embedded in Jung Tissue Freezing Medium ${ }^{5}$, wrapped in aluminum foil, immediately frozen in liquid nitrogen and stored in a freezer at $-70^{\circ} \mathrm{C}$ until immunoperoxidase and immunofluorescence assays were performed. Frozen sections of $5 \mu \mathrm{m}$ thick were fixed in $2 \%$ paraformaldehyde and treated with $0.2 \%$ hyaluronidase ${ }^{6}$ in $\mathrm{PBS}$ with $3 \% \mathrm{BSA}^{7}$.

Immunohistochemistry assay for type I collagen was performed by Avidin-Biotin Peroxidase (Hsu et al.1981) using rabbit primary monoclonal anti-bovine collagen type I antibody $^{8}$ at 1:40 dilution and Kit Elite ABC Peroxidase Vecstatin \# PK6100 Standard with secondary antibody ${ }^{9}$ (Vector Laboratories, Burlingame, CA), at 1:100 dilution. Immunohistochemistry assay for type III collagen was performed by indirect immunofluorescence (IFI) using rabbit primary monoclonal anti-bovine collagen type III antibody ${ }^{10}$ at 1:20 dilution and Goat secondary anti-rabbit IgG antibody to types I, II and III collagens ${ }^{11}$ at 1:100 dilution.

The evaluation of types I and III collagens were semiquantitative with scores from 1 to 4 (1=minimal, 2=mild, 3=moderate, 4=severe). The IFI technique was performed

\footnotetext{
${ }^{4}$ Software KS-300, Carl Zeiss, Hallbergmoos, Germany.

${ }^{5}$ Leica, Bannockburn, IL.

${ }^{6}$ Sigma, Saint Louis, MO.

7 Sigma.

${ }^{8}$ Biodesign, Saco, ME.

${ }^{9}$ Vector Laboratories, Burlingame, CA.

${ }^{10}$ Biodesign.

${ }^{11}$ Santa Cruz, São Paulo, Brazil.
}

following the manufacturer protocol for the primary antibodies (Biodesign).

Statistics. Morphometric analysis of total collagen and elastic fibers and quantification of sinusoidal cells were evaluated by variance analysis (ANOVA) of repetitive measurements and the Friedman test. Results were expressed as mean \pm the standard deviation and medians. Multiple comparisons for variable differences were performed by the Student-Newman-Keuls (SNK) method.

Correlations between different variables were calculated by Spearman rank coefficient and Pearson rank coefficient was used for correlations between total sinusoidal cells and hepatocytes. All statistical analyses were performed using Sigma Stat 2.0 software (Jandel Corporation) and differences were considered significant when $p<0.05$.

\section{RESULTS}

\section{Clinical and necropsy findings}

At the beginning of the $3^{\text {rd }}$ week some of the calves presented anorexia, tenesmus, with dry and hard feces. Due to these clinical signs, plant administration was discontinued on the $24^{\text {th }}$ day of the experiment. One calf died on the $45^{\text {th }}$ day; the remaining four calves were euthanatized at $60^{\text {th }}$ day of the experiment. At postmortem examination all five calves had shrunken and fibrotic livers, ascites and edema of the mesentery, gastric wall, gallbladder wall and subcutaneous tissue, characteristic lesions of Senecio spp poisoning in cattle (Barros et al. 1992).

\section{Microscopic findings}

The results summarized in Table 1 show that some of the microscopic changes were apparent from T2 and others from T3 on. Fibrosis was progressive and was first observed in the portal tracts and central zone followed by pericellular (Fig.1 and 2). Some small hepatic veins were occluded by fibrosis. Hepatocellular necrosis and megalocytosis and increase in sinusoidal cell numbers were present in T3, T4 and T5. Necrosis was consistently seen as individual hepatocyte necrosis, without confluence. Apoptosis was always present and peaked at T3. Some samples presented eosinophilic droplets inclusions in the

Table 1. Intensity of the lesions determined by light microscopy in the livers of five calves experimentally poisoned by Senecio brasiliensis

\begin{tabular}{|c|c|c|c|c|c|c|c|c|c|}
\hline \multirow[t]{3}{*}{ Time } & \multicolumn{4}{|c|}{ Hepatocytes } & \multirow{2}{*}{\multicolumn{3}{|c|}{$\frac{\text { Extracellular matrix }}{\mathrm{F}}$}} & \multirow[t]{3}{*}{ I } & \multirow[t]{3}{*}{ ISC } \\
\hline & \multirow[t]{2}{*}{$\mathrm{N}^{\mathrm{a}}$} & \multirow[t]{2}{*}{$\mathrm{S}$} & \multirow[t]{2}{*}{$\mathrm{M}$} & \multirow[t]{2}{*}{$\bar{A}$} & & & & & \\
\hline & & & & & PT & $\mathrm{CL}$ & $\mathrm{PC}$ & & \\
\hline $\mathrm{T} 1$ & 0 & 0 & 0 & 0 & 0 & 0 & 0 & 0 & 0 \\
\hline T2 & 0 & 0 & 0 & $1^{b}$ & 1 & 1 & 1 & $0^{c}$ & 0 \\
\hline T3 & $3^{d}$ & 1 & $2^{e}$ & $4^{f}$ & 2 & 2 & 1 & 1 & 2 \\
\hline T4 & 2 & 3 & 3 & 3 & 2 & 3 & 2 & 1 & 3 \\
\hline T5 & 2 & 1 & 4 & 1 & 4 & 3,5 & 3 & 1 & 3,5 \\
\hline
\end{tabular}

a $\mathrm{N}=$ necrosis, $\mathrm{S}=$ steatosis, $\mathrm{M}=$ megalocytosis, $\mathrm{A}=$ apoptosis, $\mathrm{F}=$ fibrosis, I = inflammation, ISC = increase of sinusoidal cells, PT = portal tract, $\mathrm{CL}=$ centrilobular, $\mathrm{PC}=$ pericellular.

${ }^{b}$ Minimal, cabsent, ${ }^{d}$ moderate, ${ }^{e}$ mild, ${ }^{f}$ severe.

$\mathrm{T}_{1}=$ control, $\mathrm{T}_{2}=15^{\text {th }}, \mathrm{T}_{3}=30^{\text {th }}, \mathrm{T}_{4}=45^{\text {th }}$, and $\mathrm{T}_{5}=60^{\text {th }}$ 


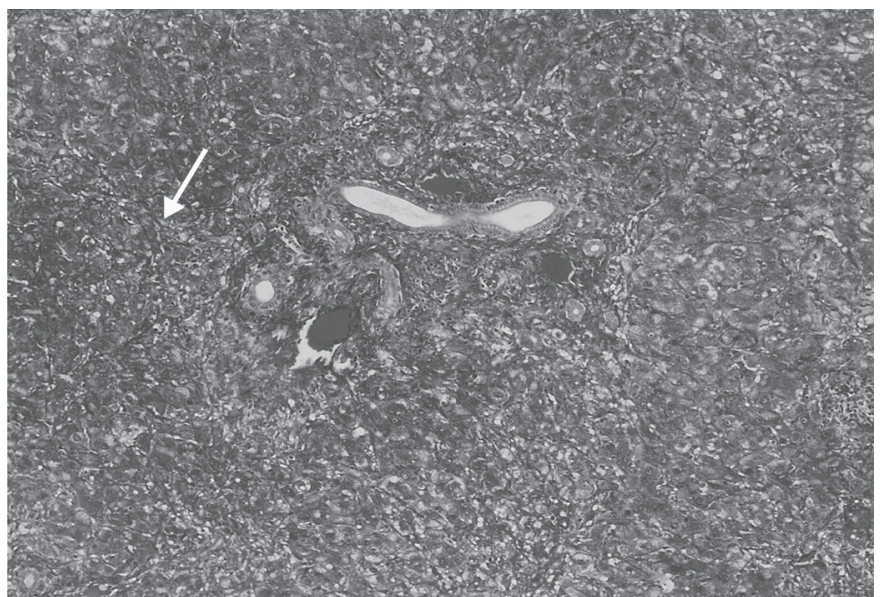

Fig.1. Fibrosis in portal tract and pericellular zone (arrow) of the liver in T3. Masson's Trichrome, obj.25x.

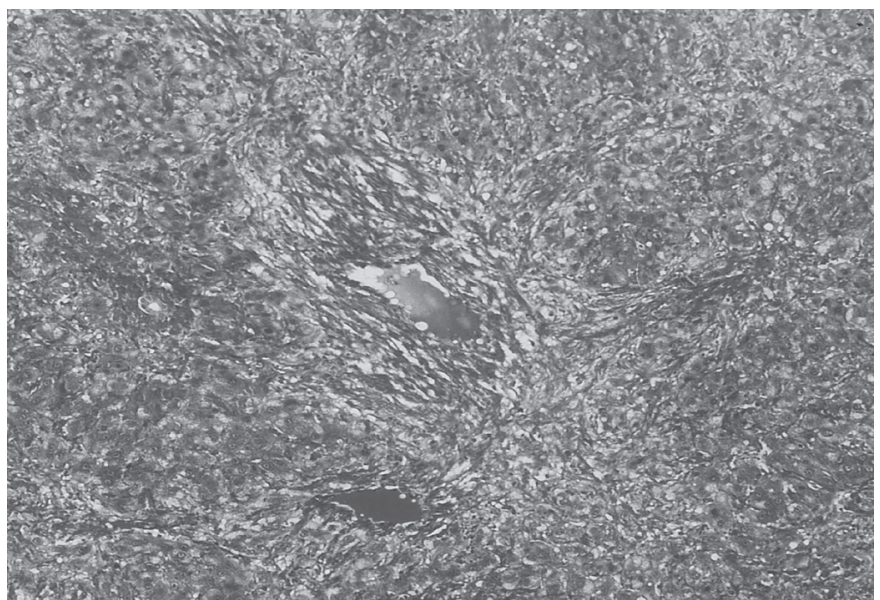

Fig.2. Hepatic centrolobular fibrosis in $\mathrm{T}_{4}$. Masson's Trichrome, obj.25x.

cytoplasm of hepatocyte and Kupffer cells. Inflammation was very consistently mild.

\section{Descriptive and morphometric analyses of total collagen and elastic fibers}

Morphometric analysis of total collagen content was assessed by digital image analysis on sections stained by the Picrossirius Red. The median of twenty fields of each sample time was compared with different sample times. Increase of collagen fibers was progressive and significant in all the times from $\mathrm{T} 1$ to $\mathrm{T} 5$. These results are presented in Figure 3.

Elastic fibers at T1 were well organized in the blood vessels wall and also present as thin fibrils through portal collagen. However, they were absent in pericellular and centrilobular compartments. At T3 they were thicker through portal collagen fibers and were irregular in wall of blood vessels in portal tracts (PT). At T4, irregular and thick elastic fibers were observed in the wall of centrilobular veins. The quantitative results for elastic fibers are presented in Figure 4, showing significant increase at T3, T4 and T5 when

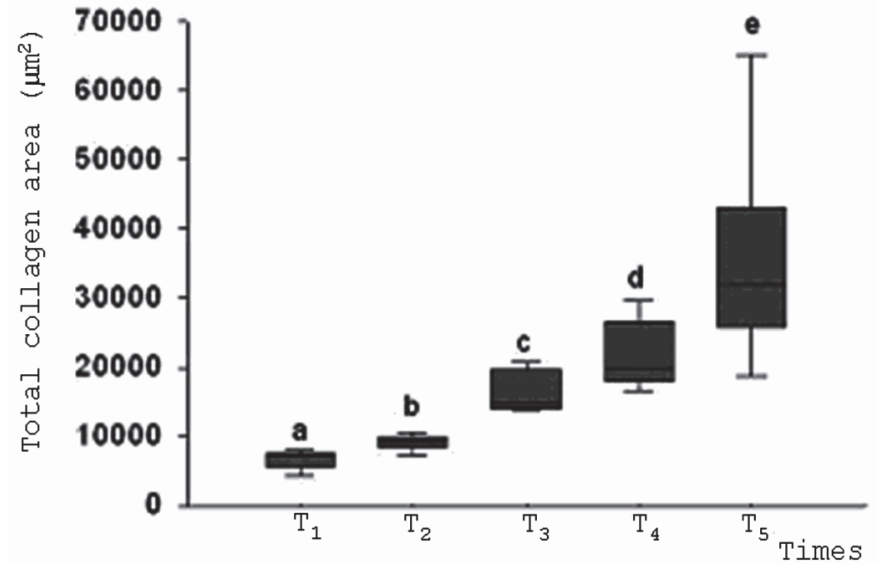

Fig.3. Box plot showing the medians of the areas occupied by total collagen $\left(\mathrm{mm}^{2}\right)$ in 20 fields of five biopsies at each time. When comparisons are statistically different $(p<0.05)$ they are identified with different letters.

compared to T2, but not when compared to each other. A positive correlation between collagen and elastic fiber density was also observed $(r=0.638 ; p<0.001)$.

\section{Immunohistochemistry, semi-quantitative analysis of collagen types I and III}

Type I collagen at T1 biopsies was mainly observed in PT and in lesser amount around centrilobular veins and sinusoids; in all experimental times this collagen type was the major component of the PT fibrous connective tissue. A similar distribution was observed for type III collagen: Deposits of thick bundles of this collagen type were observed in PT and a thin discontinuous fluorescence was observed in Disse's spaces at T1. As the fibrosis progressed collagen, type I and III increased in the same areas; they were more conspicuous in $\mathrm{PT}$ followed by the perisinusoidal compartment and then around the centri-lobular veins. The scores for collagenous fibers for each time examined in different compartments are presented in Table 2 and 3.

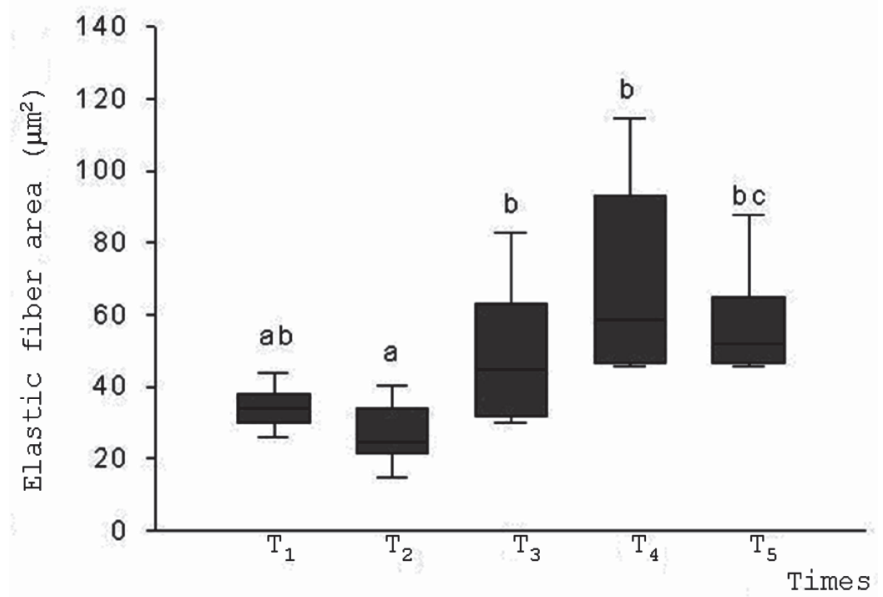

Fig.4. Box plot showing the medians of the areas occupied by elastic fibers $\left(\mathrm{mm}^{2}\right)$ in 10 fields of five biopsies at each time. When comparisons are statistically different $(p<0.05)$ they are identified with different letters. 
Table 2. Semi-quantitative analysis of collagen I by IFI at five times during experimental poisoning by Senecio brasiliensis in calves

\begin{tabular}{|c|c|c|c|c|c|c|c|c|c|c|c|c|c|c|c|}
\hline \multirow[t]{2}{*}{ Time } & \multicolumn{3}{|c|}{ Calf 1} & \multicolumn{3}{|c|}{ Calf 2} & \multicolumn{3}{|c|}{ Calf $3^{a}$} & \multicolumn{3}{|c|}{ Calf 4} & \multicolumn{3}{|c|}{ Calf 5} \\
\hline & $\mathrm{PT}^{\mathrm{b}}$ & $\mathrm{CL}$ & $\mathrm{PC}$ & PT & $\mathrm{CL}$ & $\mathrm{PC}$ & PT & $\mathrm{CL}$ & $\mathrm{PC}$ & PT & $\mathrm{CL}$ & $\mathrm{PC}$ & PT & $\mathrm{CL}$ & PC \\
\hline $\mathrm{T}_{1}$ & ++ & + & + & + & + & + & + & + & + & + & + & + & + & + & + \\
\hline $\mathrm{T}_{2}$ & +++ & ++ & ++ & ++ & + & ++ & ++ & + & + & + & + & + & + & + & + \\
\hline $\mathrm{T}_{3}$ & ++ & + & ++ & ++ & + & + & +++ & ++ & ++ & ++ & + & + & ++ & ++ & ++ \\
\hline $\mathrm{T}_{4}$ & +++ & +++ & +++ & ++ & ++ & ++ & +++ & ++ & +++ & ++ & ++ & ++ & ++++ & ++++ & ++++ \\
\hline $\mathrm{T}_{5}$ & ++++ & ++++ & ++++ & +++ & +++ & +++ & - & - & - & +++ & ++ & +++ & +++ & ++ & ++++ \\
\hline
\end{tabular}

a Died on 45th day, ${ }^{\mathrm{b}} \mathrm{PT}=$ portal tract, ${ }^{\mathrm{C}} \mathrm{CL}=$ centrilobular, $\mathrm{d} \mathrm{PC}=$ pericellular.

$\mathrm{T}_{1}=$ control, $\mathrm{T}_{2}=15^{\text {th }}, \mathrm{T}_{3}=30^{\text {th }}, \mathrm{T}_{4}=45^{\text {th }}$, and $\mathrm{T}_{5}=60^{\text {th }}$.

Table 3. Semi-quantitative analysis of collagen III by IFI at five times during experimental poisoning by Senecio brasiliensis in calves

\begin{tabular}{|c|c|c|c|c|c|c|c|c|c|c|c|c|c|c|c|}
\hline \multirow[t]{2}{*}{ Time } & \multicolumn{3}{|c|}{ Calf 1} & \multicolumn{3}{|c|}{ Calf 2} & \multicolumn{3}{|c|}{ Calf $3^{a}$} & \multicolumn{3}{|c|}{ Calf 4} & \multicolumn{3}{|c|}{ Calf 5} \\
\hline & $\mathrm{PT}^{\mathrm{b}}$ & $\mathrm{CL}$ & $\mathrm{PC}$ & PT & $\mathrm{CL}$ & $\mathrm{PC}$ & PT & $\mathrm{CL}$ & $\mathrm{PC}$ & PT & $\mathrm{CL}$ & PC & PT & $\mathrm{CL}$ & $\mathrm{PC}$ \\
\hline $\mathrm{T}_{1}$ & ++ & ++ & ++ & ++ & ++ & + & + & + & + & ++ & + & + & ++ & ++ & ++ \\
\hline $\mathrm{T}_{2}$ & ++ & ++ & ++ & + & + & ++ & ++ & + & + & ++ & ++ & ++ & ++ & + & + \\
\hline $\mathrm{T}_{3}$ & ++ & ++ & ++ & ++ & ++ & ++ & +++ & +++ & +++ & ++ & ++ & ++ & +++ & ++ & ++ \\
\hline $\mathrm{T}_{4}$ & ++++ & +++ & +++ & +++ & +++ & +++ & +++ & ++ & +++ & ++ & ++ & ++ & +++ & +++ & +++ \\
\hline $\mathrm{T}_{5}$ & ++++ & ++ & +++ & ++++ & +++ & ++++ & - & - & - & ++++ & ++ & +++ & ++++ & ++++ & ++++ \\
\hline
\end{tabular}

a Died on 45th day, ${ }^{\mathrm{b}} \mathrm{PT}=$ portal tract, ${ }^{\mathrm{c}} \mathrm{CLV}=$ centrilobular, $\mathrm{d} P \mathrm{C}=$ pericellular.

$\mathrm{T}_{1}=$ control, $\mathrm{T}_{2}=15^{\text {th }}, \mathrm{T}_{3}=30^{\text {th }}, \mathrm{T}_{4}=45^{\text {th }}$, and $\mathrm{T}_{5}=60^{\text {th }}$.

\section{Ultrastructural findings}

Descriptive analysis of hepatocyte lesions. Some hepatocytes at T2 had irregular nuclear membranes with finger-like projections, dilated mitochondria and some myelin bodies. Hepatocyte necrosis and apoptosis as well as $\mathrm{Ku}$ pffer cell phagocytosing cellular debris were observed at T3. Eosinophilic intracytoplasmic inclusions seen by light microscopy were likely to be fragments of apoptotic bodies phagocytosed by Kupffer cells or by neighboring hepatocytes.

\section{Morphologic analysis and quantification of sinusoidal cells}

Quantification of sinusoidal cells was based on the morphology of each cell, normally accessible until T3. The majority of hepatic stellate cells had only one intracyto-plasmic lipid droplet per cell (Fig.5). The Kupffer cells increased at T3 when compared to T1 and T2; liver associate lymphocytes were also increased $(p<0.05)$ at T3. Within the same time the endothelial cells decreased at T2 and T3 and the hepatic stellate cells were also reduced at T3 $(p<0.05)$.

Morphologic distinction of different sinusoidal cells was not possible after T4, since the hepatic stellate cells had no more than one lipid droplet; elongated cells with oval nuclei or with prominent rough endoplasmic reticulum were observed in close association with many collagen fibrils which were also seen in the intracytoplasmic compartment (Fig.6 and 7). A quantification of total sinusoidal considering the number of hepatocytes at the five sampling times is presented in Figure 8 and 9. An increase of total sinusoidal cells was observed at T4 and T5 and a decrease in hepatocyte numbers was observed from T3 to T5 $(p<0.05)$. There was a positive correlation of sinusoidal cells and collagen fibers $(r=0.602 ; p<0.001)$, while that correlation between total sinusoidal cells and hepatocytes was negative $(r=-0.753 ; p<0.001)$.

\section{DISCUSSION}

Clinical and necropsy findings in our calves were similar to that described in cases of spontaneous and experimental poisoning by Senecio spp. in cattle (Méndez et al. 1987, Hill et al. 1997, Barros et al 1992, Basile et al. 2005). However, clinical signs were observed earlier in the present

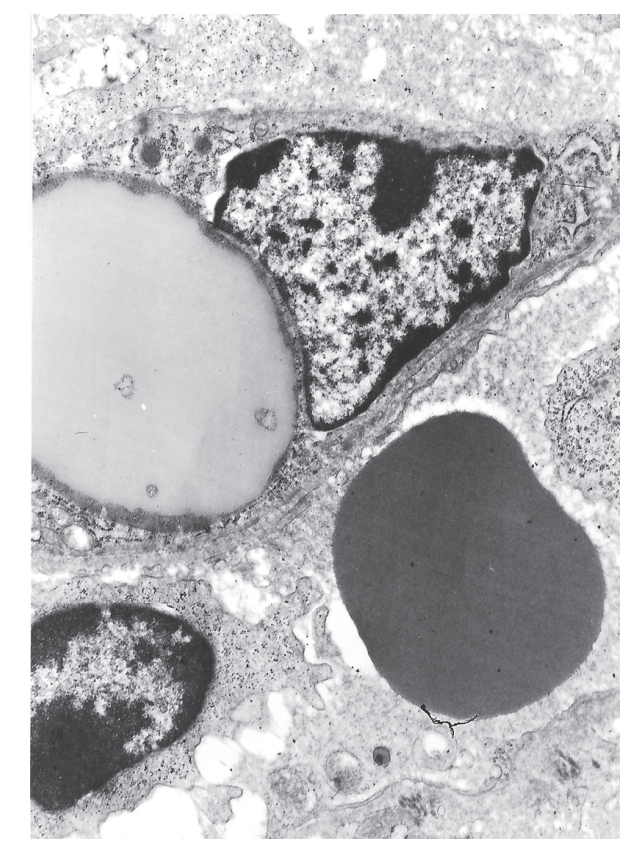

Fig.5. Normal hepatic stellate cell shows only one big lipid droplet at $\mathrm{T}_{1}$. Transmission electron microscopy, 7,000x. 

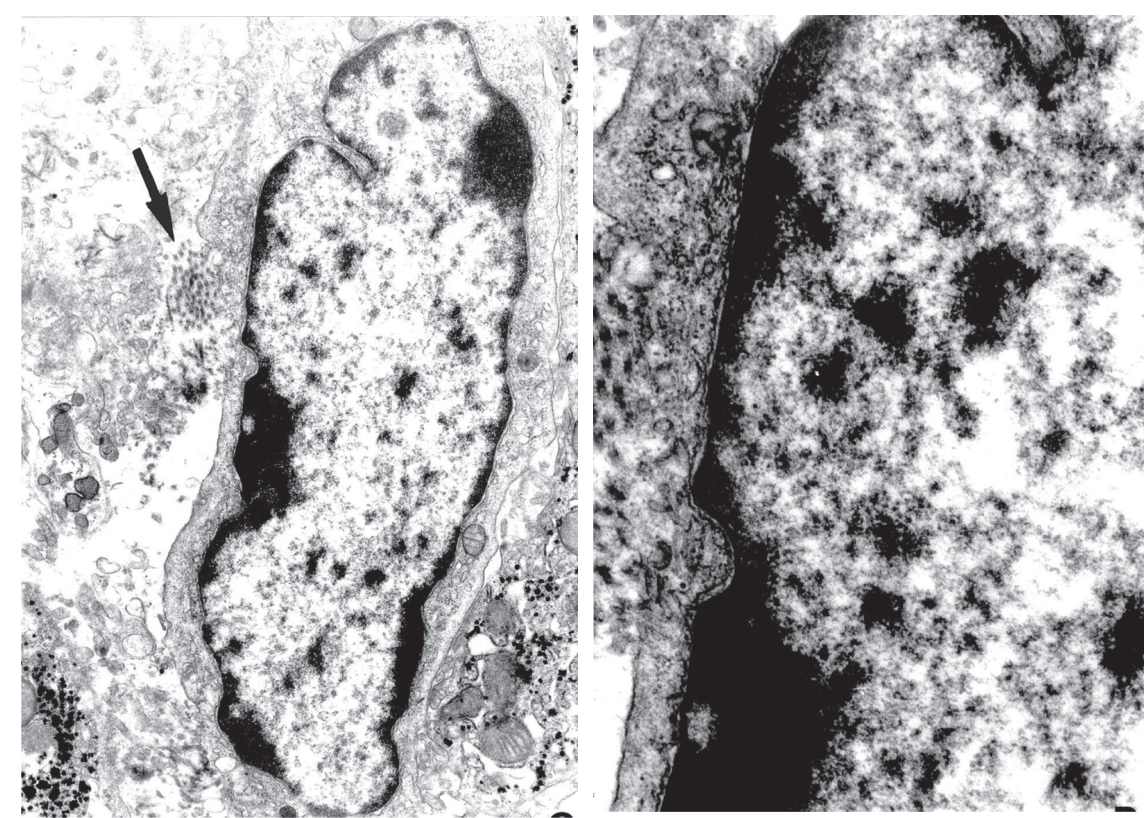

Fig.6. Transitional cells in the liver originated from hepatic stellate cells closely associated to many collagen fibrils (arrow) which were also seen in intracytoplasmic compartment at $T_{5}$. Transmission electron microscopy, 7,000x.

Fig.7. Higher magnification of the transitional cells in the liver originated from hepatic stellate cells shown in Fig.6 at $T_{5}$. Transmission electron microscopy, 20,000x.

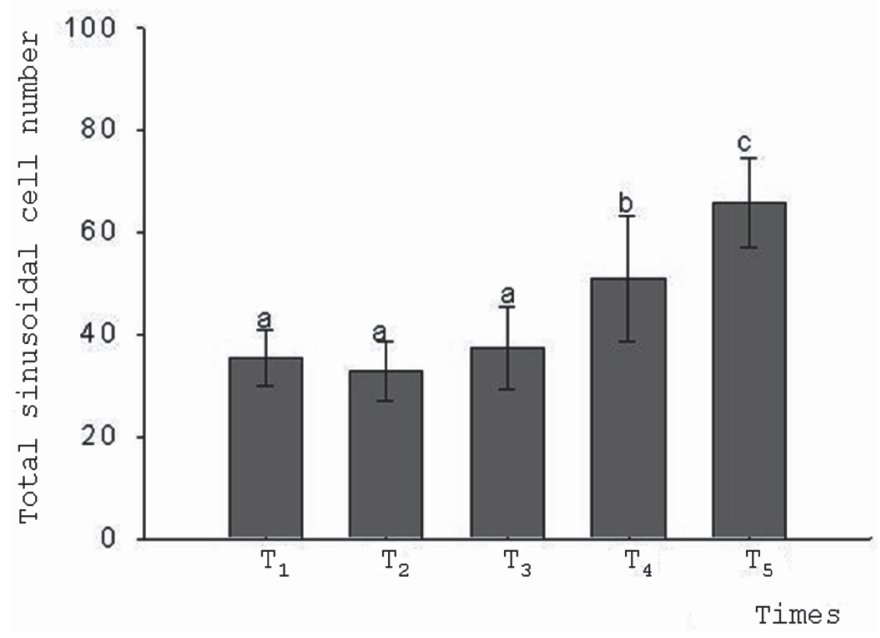

Fig.8. Total number of sinusoidal cells in hepatic biopsies of five times of the lesion. When comparisons are statistically different $(p<0.05)$ they are identified with different letters.

experiment than those observed in other studies (Méndez et al. 1987, Barros \& Driemeier, 1992).

In our experiment the fibrotic lesion was progressive from T2 to T5, even when the plant administration was discontinued. This finding is similar to those observed in other experimental poisoning trials in cattle poisoned by other Senecio spp. (Craig et al. 1991) and by S. brasiliensis (Tokarnia \& Döbereiner 1984). Regression of stablishe lesions in pirrilozidne alkaloid (PA) poisonig is rare, although some cases have been reported in human beings (Sperl et al. 1995) and horses (Mendel et al. 1988). Hepatocellular

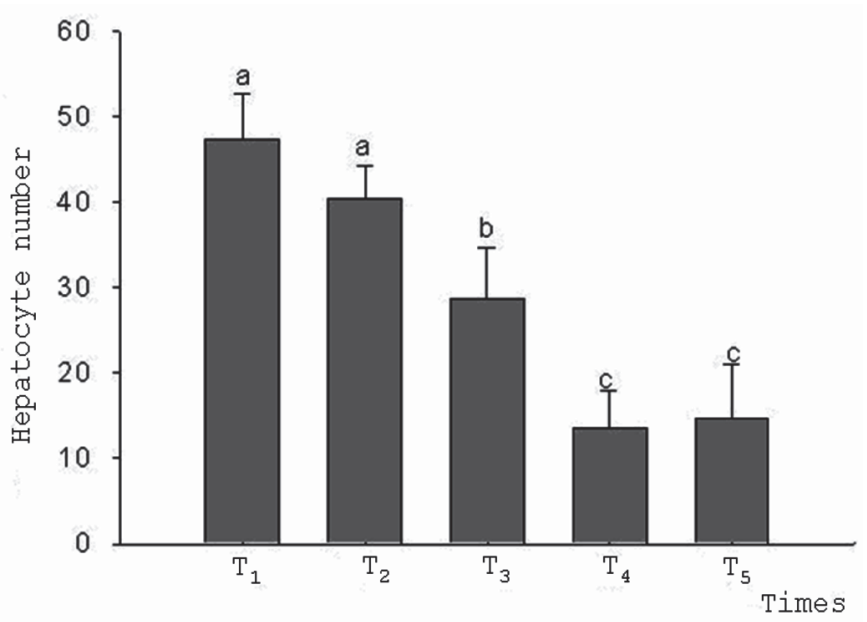

Fig.9. Number of hepatocytes in the lesion from hepatic biopsies of five times. When comparisons are statistically different $(p<0.05)$ they are identified with different letters.

megalocytosis, which has been referred to as the pathologic hallmark of PA toxicosis (Bull et al. 1969), was evident in this study at T3 and was progressive until T5. Megalocytosis is characterized by hepatocyte enlargement and nuclear hyperchromatims. It appears to result from a combined action of PA on the hepatocyte, a regenerative stimulus following parenchymal cell injury, and the powerful antimitotic action of the pyrrole metabolites (WHO 1988) of PAs. Other liver changes in this study were also similar to those described in other PA toxicoses in domestic animals (Barros \& Driemeier 1992, Barros et al. 1992, Torres et al. 1997). 
With respect to the hepatic ECM changes, fibrosis was observed at T3, initially in the PT and subsequently in the parenchyma. This finding is similar to that described in other experiments with PA toxicosis in domestic animals (Walker \& Kirkland 1981). Centrilobular fibrosis has rarely been described as an important lesion (Seawright et al. 1991, Odriozola et al. 1994). Fibrosis is a non-specific and common finding in a variety of hepatic diseases (Grimaud et al. 1980, Martinez-Hernandez 1984, Clement et al. 1986, Takahara et al. 1988, Loreal et al. 1992, Sato et al. 2000). The centrilobular fibrosis observed in this study could result from endothelial cell lesion (De Leve et al. 2002) or zonal hepatocellular necrosis (Martinez-Hernandez 1985, Takahara et al. 1988). In the present study the portal fibrosis was an early and prominent feature, but its pathogenesis is still unclear.

Collagen is the main component of hepatic ECM and is markedly increased in several chronic liver diseases regardless it's the etiology (Takahara et al. 1988). Collagen type I predominated at T1, in the portal and centrilobular locations and was associated with some collagen type III, which predominated in pericellular location. Increasing of fibrosis was accompanied by an increasing in type I collagen pericellular sites. Although type III collagen increased in portal and centrilobular locations, type I collagen predominated at T5 in these compartments. The morphometric analysis showed significant and progressive increase of total collagen at the different time points of the lesion that were examined.

Although we were unable to find any reference in the literature to either qualitative or quantitative collagen analysis in normal or chronically damaged livers in cattle, the results of indirect immunofluorescence (IFI) immunohistochemistry are similar to those observed in natural occurring liver cirrhosis of human beings and experimental induced cirrhosis in rats (Clement et al. 1986, Benyon et al. 1998).

In this experiment there was a significant and positive correlation between the increase of total collagen and elastic fibers, although the increase in elastic fibers was neither progressive nor regular. The alterations of location and array of the elastic fibers suggest that these factors are more relevant and probably associated with the alterations of blood pressure in the liver with the progression of fibrosis. This fact may be the reason for increasing of fibrosis in man, rat and baboons has not been associated with increase of elastin (Porto et al. 1990). The significant increase in elastic fibers is thought to occur later in cases of cirrhosis (Bartok et al. 1979) that occurred in the present trial.

The increase of sinusoidal cells was related to the severity of lesions and there was a significant positive correlation with the increase of collagen. Sinusoidal cells are involved in the synthesis and degradation of the ECM, and the hepatic stellate cells are considered to be the main ECM producers in normal and fibrotic livers (Takahara et al. 1988, Tanikawa 1999, Sokol 2002). Immunohistochemistry performed with monoclonal antibodies is described as the best method for quantification of these cells in humans and rats (Takahara et al. 1988, Burt et al.
1993), but there are no currently available antibodies for bovines; for this reason our quantifications were performed using transmission electron microscopy.

The increase of Kupffer cells is associated with the cytosolic factors released by necrotic hepatocytes (Burt et al. 1993) and to the initial presence of activation markers of hepatic stellate cells (Sokol 2002). From T4 on many cells presented elongated nuclei and rough endoplasmic reticulum hyperplasia; these findings corroborated with other studies, which reported transitional cells originated from hepatic stellate cells in chronic hepatic lesions of different etiologies (Mak et al. 1984, Mak \& Lieber 1988, Benyon et al. 1998). In addition, we observed that the bovine hepatic stellate cells at T1 have only one large lipid droplet, a situation similar to that observed in the pig liver, in the which hepatic stellate cells have only one or two lipid droplets (Bartok et al. 1979). For this reason, it was not possible to evaluate these cell changes in respect to the decrease of droplet numbers as reported in humans and monkeys (Mak et al. 1984, Mak \& Lieber 1988).

The increased number of transitional, myofibroblast and fibroblast like cells was responsible for the increase of the sinusoidal cells at day 45 and 60 and a significant positive correlation with increase of collagen. These findings reinforce the importance of sinusoidal cells on the production of collagen (Takahara et al. 1988, Benyon \& Iredale 2000). The negative correlation with the number of hepatocytes resulted from necrosis and/or apoptosis of these cells by toxic action of the PAs.

During hepatic fibrosis endothelial cells experience further phenotypic alterations with loss of fenestrations and formation of typical basement membrane (MartinezHernandez 1984). The mechanism of the liver associated lymphocytes increase at T3 is similar to that observed in cirrhosis and pre-neoplastic lesions caused by carbon tetrachloride $\left(\mathrm{CCl}_{4}\right)$ in rats. There was an increase in CD5and CD8- positive cells e augmentation of lecitindependent cellular cytotoxicity (LDCC) activity in liver associated lymphocytes during development of preneoplastic lesions, which may imply that intrahepatic cellular immunity against the pre-neoplastic lesions is affected in liver cirrhosis (Takashi et al. 2000).

In summary, sinusoidal cells, mainly activated by hepatic stellate cells might produce a fibrogenic environment within the liver through a combination of ECM overproduction, diminished metaloproteinase (MMP) activation and inhibition of active metaloproteinases by tissue inhibitors. A complete anatomic recovery from liver fibrosis would require remodeling and breakdown of ECM components (Benyon \& Iredale 2000). The present experiment is a suitable model of chronic hepatic cirrhosis in cattle, since it is a progressive and irreversible injury, allowing observation of different components of matrix and sinusoidal cells. The analysis of hepatic biopsies at day 0 established the normal pattern of ECM and may be useful in other experiments as well as in the study of natural chronic hepatic disease in cattle. 


\section{REFERENCES}

Albert B., Bray D., Lewis J., Raff M., Roberts K. \& Watson J. 1994. Molecular biology of the cell, p.949-1009. In: Birk D., Cohen R., Geiger B., Goodenough D., Guabiner B., Hynes R., Reichard L., Ruislahti G., Trelstad R., Wolsh F. \& Yerchanco P. (ed.), Cell Junctions, Cell Adhesion, and the Extracellular Matriz. 3rd ed. Garland Publishing, London.

Barros C.S.L \& Driemeier D. 1992. Intoxicação experimental por Senecio oxyphyllus (Compositae) em bovinos. Pesq.Vet.Bras.12(1/2):3342.

Barros C.S.L., Driemeier D., Pilati C., Barros S.S. \& Castilho L.M.L. 1992. Senecio spp. poisoning in cattle in southern Brazil. Vet. Human Toxicol. 34(3):241-246.

Bartok I., Jeannette T., Remenar E. \& Viragh S.H. 1979. Ultrastructure of the hepatic perisinusoidal cells in man and mammalian species. Anat. Rec. 194:571-586.

Basile J.R., Diniz J.M.F., Okano W., Sírio S.M. \& Leite L.C. 2005. Intoxicação por Senecio spp. (Compositae) no Sul do Brasil. Act. Sci. Vet. 33(1):63-68.

Benyon R., Chistopher A. \& Michael J.P. 1998. Mechanisms of hepatic fibrosis. J. Ped. Gastr. Nutr. 27(1):75-85.

Benyon R.C. \& Iredale J.P. 2000. Is liver fibrosis reversible? Int. J. Gastroenterol. Hepatol. 46(4):443-446.

Bull L.B., Culvenor C.C.J. \& Dick A.T. 1969. The pyrrolizidine alkaloids: Their chemistry, pathogenicity and other biological properties. NorthHolland Publ., Amsterdam. 293p.

Burt A.D., Le Bail B., Balabaud C. \& Bioulac-Sage P. 1993. Morphologic Investigation of sinusoidal cells. Seminars in Liver Disease 13(Suppl.1):21-38.

Clement B., Grimaud J.A., Campion J.P., Deugnier I. \& Guillouzo A. 1986. Cell types involved in collagen and fibronectin production in normal and fibrotic human liver. Hepatol. 6(Suppl 2):225-234.

Craig A.M., Pearson E.G., Meyer C. \& Schmit J.A. 1991. Serum liver enzyme and histopathologic changes in calves with chronic and chronic-delayed Senecio jacobaea toxicosis. Am. J. Vet. Res. 52(12):1969-1978.

De Leve L., Shulman H.M. \& McDonald G.B. 2002. Toxic injury to hepatic sinusoids: sinusoidal obstruction syndrome (veno-occlusive disease). Seminars in Liver Disease 22(1):27-38.

Geerts A. 2001. History, heterogeneity, developmental biology, and functions of quiescent hepatic stellate cells. Seminars in Liver Disease 21(Suppl.3):311-335.

Grimaud J.A., Druguet M., Peyrol S., Chevalier O., Herbage D. \& Badrawy N. 1980. Collagen immunotyping in human liver: light and eletronic microscope study. J. Histochem. Cytochem. 28(11):1145-1156.

Hill B.D., Gaul K.L. \& Noble J.W. 1997. Poisoning of feedlot cattle by seeds of Heliotropium europaeum. Aust. Vet. J. 75(5):360-361.

Hsu S.M., Raine L. \& Fanger N.1981. Use of avidin-biotin-peroxidase complex $(\mathrm{ABC})$ and unlabeled antibody (PAP) procedures. J. Histochem. Cytochem. 29:577-580.

James J., Bosch K.S., Aronson D.C. \& Houtkooper J.M. 1990. Sirius Red histophotometria and spectrophotometry of sections in the assessmente of the collagen content of liver tissue and its applications in growing rat liver. Liver 10:1-5.

Loreal O., Clément B., Schuppan D., Rescan P.Y., Rissel L.M. \& Guillouzo A. 1992. Distribution and cellular origin of collagen VI during development and in cirrhosis. Gastroenterol. 102:980-987.

Mak K.M., Leo M.A. \& Lieber C.S. 1984. Alcoholic liver injury in baboons: transformation of lipocytes to transitional cells. Gastroenterol. 87:188200.

Mak K.M. \& Lieber C.S. 1988. Lipocytes and transitional cells in alcoholic liver disease: a morphometric study. Hepatol. 8(5):1027-1033.

Martinez-Hernandez A. 1984. The hepatic extracellular matrix: Electron immunohistochemical studies in normal rat liver. Lab. Invest. 51(1):5774.

Martinez-Hernandez A. 1985. The hepatic extracellular matrix. II. Electron immunohistochemical studies in rats with CCl4-induced cirrhosis. Lab. Invest. 53(2):166-186

Medeiros M.B.A., Souza F.F., Neto P.I.S. \& Coelho K.I.R. 2002. Técnica de biópsia hepática guiada pelo ultra-som em bezerros. Revta Educ. Cont. CRMV-SP, São Paulo, 5(1):94-99.

Mendel V.E., Witt M.R., Gitchel B.S., Gribble D.N., Rogers Q.R., Segal H.J. \& Knight H.D. 1988. Pyrrolizidine alkaloid-induced liver disease in horses: an early diagnosis. Am. J. Vet. Res. 49(4):572-578.

Méndez M.C., Riet-Correa F. \& Schild A.L. 1987. Intoxicação por Senecio spp. (Compositae) em bovinos no Rio Grande do Sul. Pesq.Vet.Bras. 7:51-56.

Montes G.S. 1992. Distribution of oxytalan, elaunin and elastic fibres in tissues. Ciência e Cultura, Rio de J., 44:224-233.

Odriozola E., Campero C., Casaro A., Lopez T., Olivieri G. \& Melucci O. 1994. Pyrrolizidine alkaloidosis in argentinian cattle caused by Senecio selloi. Vet. Human. Toxicol. 36(3):205-208.

Olaso E. \& Friedman S.L. 1998. Molecular regulation of hepatic fibrogenesis. Journal of Hepatol. 29:836-847.

Porto L.C., Chevalier M., Peyrol S., Guerret S. \& Grimaud J. A. 1990. Elastin in human, baboon, and mouse liver: an immunohistochemical and immunoelectron microscopic study. Anatomic Rec. 222:392-404.

Prakash S.A., Pereira T.N., Reilly P.E.B. \& Seawright A.A. 1999. Pyrrolizidine alkaloids in human diet. Mut. Res. 443:53-67.

Ridker P.M., Seitaro O., McDermott W.V., Trey C. \& Huxtable R.J.H. 1985. Hepatic venocclusive disease associated with the consumption of pyrrolizidine-containing dietary supplements. Gastroenterol. 88(4):1050-1054.

Sato S., Adachi A. \& Wakamatsu K. 2000. Abnormal elastic system fibers in fibrotic human liver. Med. Electron. Microsc. 33:135-142.

Schuppan D., Ruehl M., Somasundaran R. \& Hahn E.G. 2001. Matrix as a modulator of hepatic fibrogenesis. Seminars in Liver Disease 21(3):351-372.

Seawright A.A., Kelly W.R, Hrdlicka J., McMahon P., Mattocks A.R. \& Jukes R. 1991. Pyrrolizidine alkaloidosis in cattle due to Senecio species in Australia. Vet. Rec. 31:198-199.

Shiratori Y., Tananka M., Kawase T., Shiina S., Komatsu Y. \& Omata M. 1993. Quantification of sinusoidal cell function in vivo. Seminars in Liver Disease 13(1):39-49.

Sokol R.J. 2002. Liver cell injury and fibrosis. J. Pediatric. Gastroenterol. Nutrit. 35(1):S7-S10.

Sperl W., Stuppner H., Gassner I., Judmaier W., Dietze O. \& Vogel W. 1995. Reversible hepatic veno-occlusive disease in an infant after consumption of pyrrolizidine-containing herbal tea. Eur. J. Pediatr. 154:112-116.

Takahara T., Kojima T., Miyabayashi C., Kyoichi I., Sasaki H., Muragaki Y. \& Ooshima A. 1988. Collagen production in fat-storing cells after tetrachloride intoxication in the rat: Immunoelectron microscopic observation of type I, type III collagens, and prolyl hydroxylase. Lab. Invest. 59(4):509-521.

Takashi T., Shimizu Y., Higuchi K. \& Watanabe A. 2000. Effect of branched-chain amino acids on the composition and cytolitic activity of liver-associated lymphocytes in rats. Gastroenterol. Hepatol. 15(8):849-859

Tanikawa K. 1999. Stellate cell, endothelial cell and Kupffer cell: their role in liver fibrosis. J. Gastroenterol. Hepatol 14:281-282.

Tokarnia C.H. \& Döbereiner J. 1984. Intoxicação experimental por Senecio brasiliensis (Compositae) em bovinos. Pesq. Vet. Bras. 4(2):3965.

Torres M.B.A.M., Salles M.W.S., Headley A.S. \& Barros C.S.L. 1997. Intoxicação experimental por sementes de Crotalaria spectabilis (Leguminosae) em suínos. Ciência Rural, Santa Maria, 27(2):307312.

Walker K.H. \& Kirkland P.D. 1981. Senecio lautus toxicity in cattle. Aust. Vet. J. 57:1-7.

WHO 1988. Pyrrolizidine alkaloids. World Health Organization, Geneva. 